\title{
The soluble catalytic ectodomain of ACE2 a biomarker of cardiac remodelling: new insights for heart failure and COVID19
}

\author{
Artemio García-Escobar ${ }^{1}$ (D ) Santiago Jiménez-Valero ${ }^{1}$. Guillermo Galeote ${ }^{1}$ - Alfonso Jurado-Román ${ }^{1}$. \\ Julio García-Rodríguez ${ }^{2} \cdot$ Raúl Moreno $^{3}$
}

Accepted: 8 December 2020 / Published online: 6 January 2021

(C) The Author(s), under exclusive licence to Springer Science+Business Media, LLC part of Springer Nature 2021

\begin{abstract}
The angiotensin-converting enzyme 2 (ACE2) is a type I integral membrane that was discovered two decades ago. The ACE2 exists as a transmembrane protein and as a soluble catalytic ectodomain of ACE2, also known as the soluble ACE2 that can be found in plasma and other body fluids. ACE2 regulates the local actions of the renin-angiotensin system in cardiovascular tissues, and the ACE2/Angiotensin 1-7 axis exerts protective actions in cardiovascular disease. Increasing soluble ACE2 has been associated with heart failure, cardiovascular disease, and cardiac remodelling. This is a review of the molecular structure and biochemical functions of the ACE2, as well we provided an updated on the evidence, clinical applications, and emerging potential therapies with the ACE2 in heart failure, cardiovascular disease, lung injury, and COVID-19 infection.
\end{abstract}

Keywords ACE2 - soluble catalytic ectodomain of ACE2 - soluble ACE2 - Angiotensin 1-7 · cardiac remodelling · heart failure $\cdot$ lung injury $\cdot$ COVID-19 $\cdot$ SARS-CoV-2 $\cdot$ Chelation therapy

\section{The ongoing pandemic COVID19}

On late December 2019, China reported a cluster of cases of pneumonia at Wuhan, Hubei province; the pathogen was identified as a betacoronavirus in the same subgenus as the severe acute respiratory syndrome coronavirus (SARS-CoV)

Artemio García-Escobar

dr_garciaescobar@hotmail.com

Santiago Jiménez-Valero

sjvcardio@yahoo.es

Guillermo Galeote

ggaleote@gmail.com

Alfonso Jurado-Román

alfonsojuradodoroman@gmail.com

Julio García-Rodríguez

jgarciarodriguez@salud.madrid.org

Raúl Moreno

raulmorenog@hotmail.com

1 Cardiology Department, Interventional Cardiology Section, University Hospital La Paz, Madrid, Spain

2 Head of Clinical Microbiology Department, University Hospital La Paz, Madrid, Spain

3 Cardiology Department, Head of Interventional Cardiology Section, University Hospital La Paz, Madrid, Spain
[1]. The Coronaviridae Study Group of the International Committee on Taxonomy of Viruses has proposed that this virus be designated as severe acute respiratory syndrome coronavirus 2 (SARS-CoV-2) [2]. SARS-CoV-2 is the seventh coronavirus that is known to cause human disease [3].

In February 2020, the World Health Organization (WHO) designated the disease SARS-CoV-2 caused by coronavirus 2019 (COVID19), on early March 2020, the WHO declared COVID-19 to be a pandemic [4]. At this moment, there was no European Medicines Agency or Food and Drug Administration-approved drugs specifically for the treatment of this pandemic [5]. Chloroquine and hydroxychloroquine, especially the latter, is one of the most widely used drugs during the pandemic due to some studies that reported that they inhibit SARS-CoV-2 in vitro [6, 7]. One small trial, hydroxychloroquine alone, and combination with azithromycin reduced detection of SARS-CoV-2 ribonucleic acid (RNA) in the upper respiratory tract [8]. Nevertheless, a recent retrospective multicenter cohort study of patients hospitalised in metropolitan New York with COVID-19 showed that treatment with hydroxychloroquine, azithromycin, or both, compared with neither therapy, was not significantly associated with differences in in-hospital mortality [9].

Remdesivir was a promising drug during the pandemic, showing in vitro activity against SARS-CoV-2 
[10]. However, a double-blind, randomised trial in China of 237 patients with severe COVID-19 clinical improvement was not statistically different with remdesivir compared with placebo for 10 days and mortality at 28 days was also similar with remdesivir or placebo, although not statistically significant, patients receiving remdesivir had a numerically faster time to clinical improvement than those receiving placebo among patients with symptom duration of 10 days or less [11]. Also, Lopitonavir-ritonavir was used at the start of the pandemic until a randomised, controlled, open study of 199 patients with severe SARS-CoV-2 infection did not demonstrate clinical improvement or mortality at 28 days [12]. This discouraged many countries from using the drug due to important pharmacological adverse effects.

Convalescent plasma is one of the most widely studied non-pharmacological treatments at present. There are small controlled case series of patients with SARSCOV-2 and acute respiratory distress syndrome (ARDS). The administration of convalescent plasma was followed by improvement in their clinical status [13]. Similarly, other small study showed that convalescent plasma treatment can discontinue detection of viral shedding but cannot reduce mortality in critically end-stage COVID-19 patients, suggesting that treatment should be initiated earlier [14]. The limited sample size and study design preclude a definitive statement about the potential effectiveness of this treatment, and these observations require evaluation in clinical trials. Moreover, finding appropriate donors and establishing testing to confirm the neutralising activity of plasma may be logistical challenges. Furthermore, SARS-CoV-2 C-terminal domain forms more atomic interactions with angiotensin-converting enzyme 2 (ACE2) than SARS-CoV-1- receptor-binding domain (RBD), suggesting that the previously developed SARSCoV-1-RBD-based vaccine candidates are unlikely to be of any clinical benefit for SARS-CoV-2 prophylaxis [15]. Many drugs and treatments are under clinical trial [16], and their efficacy for SARS-CoV-2 remains to be determined, so far, no treatment is effective against SARSCoV-2. There are several vaccines in development with a wide range of strategies, from the traditional model based on attenuated viruses to the most revolutionary design based on mRNA or DNA. Currently, the first types of commercialised vaccines are based on SARS-CoV 2 peak RNA proteins packaged in lipid nanoparticles [17]. These types of vaccines are very specific because they are based on the synthesis of the SARS-Cov-2 peak protein.

Many studies demonstrated the ACE2 as an entry receptor for SARS-CoV-2 infection [15]. Hence, understanding the ACE2 molecular structure and biochemical functions could provide a better understanding of the SARS-COV-2 physiopathology and new insights for COVID-19 treatment.

\section{The concerns about the use of renin-angiotensin-aldosterone system inhibitor medication in COVID-19}

On early March, the first retrospective cohort studies revealed that older age, hypertension, and diabetes were risk factors associated with the development of ARDS and worse prognosis [18]. It is well known so far that SARS-CoV-2 share $79.6 \%$ sequence identity to SARS$\mathrm{CoV}-1$ and uses the same cell entry receptor ACE2 [19]. Pre-clinical studies indicated that angiotensin-converting enzyme inhibitors (ACEI) and angiotensin II receptor blockers (ARB) increased the ACE2 mRNA expression $[20,21]$. This led to speculate by some authors that the use of renin-angiotensin-aldosterone system (RASS) inhibitor medication could facilitate infection with SARS-CoV-2 and even increases the risk of developing a severe viral infection because hypertensive and diabetic patients are most often treated with those medications [22]. This has created a debate about the temporary discontinuation of RASS inhibitor medication. However, the Cardiology Scientific Societies, their position, was not to add or remove any RASS-related treatments, beyond actions based on standard clinical practice [23]. Recently, observational studies performed in Italy $(n=6272)$ and New York $(n=12,594)$ showed that there was no evidence that ACEI or ARB affected the risk of COVID-19 infection $[24,25]$.

\section{The ACE2 molecular structure}

The ACE2 is the first known human homologue of angiotensin-converting enzyme (ACE) discovered in 2000 $[26,27]$. The ACE2 gene contains 18 exons, interspersed with 17 introns, localised to chromosome $\mathrm{X}$, position p22.2 [26]. The ACE2 is a type I integral membrane protein of 805 amino acids that contains two domains [26-28], the first a transmembrane domain (amino acids 741-763) [27] and the second is an extracellular region, also known as the ectodomain (amino acids 1-740). The extracellular region is composed of two domains [28]; the first is a zinc metallopeptidase domain (amino acids 19-611) that is the single catalytic domain of the ACE2 $[26,27]$, which is $42 \%$ identical to each of the two catalytic domains in ACE [27]; the second is located at the $\mathrm{C}$ terminus (amino acids 612-740) is $48 \%$ identical to a transporter protein known as collectrin. The crystal structure revealed that ACE2 contains $20 \alpha$-helical segments [28].

The metalloprotease domain of ACE2 can be further divided into two subdomains (I and II) which form the 
two sides of a long and deep cleft with dimensions of $\sim 40 \AA$ long by $\sim 15 \AA$ wide by $\sim 25 \AA$ deep. The two subdomains are connected only at the floor of the active site cleft. One prominent $\alpha$-helix (helix 17, residues 511531) connects the two subdomains and forms part of the floor of the canyon. There are three disulfide bonds of ACE2 (Cys133-Cys141, Cys344-Cys361, and Cys530Cys542). The zinc-binding site is located near one side of the large active site cleft (subdomain I); the zinc is coordinated by His374, His378, Glu 402, and one water molecule (in the native structure). A chloride ion (Cl-) is bound in native ACE2, coordinated by Arg 169, Trp477, and Lys481 in subdomain II [28].

The ACE2 protein at the extracellular region has the catalytically active ectodomain that undergoes shedding by a disintegrin and metalloproteinase domain-containing protein 17 (ADAM17) also known as tumour necrosis factor alpha-converting enzyme, a protease up-regulated in heart failure (HF) [29]. This ADAM17 releases a soluble form of ACE2 (Fig. 1). The region of ACE2 cleavage is localised between amino acids 716 and 741, near the predicted transmembrane domain [30]. Some studies suggest that a calcium signalling pathway is involved in ACE2 release [29, 30]. Calmodulin is a ubiquitous calcium-binding protein which is known to bind other transmembrane proteins, including L-selectin and ACE, and regulate their cell surface expression. Lambert et al. demonstrated in vitro that calmidazolium (calmodulin antagonist) resulted in increased soluble ACE2 activity. This calmidazolium-mediated stimulation of ACE2 shedding was time- and dose-dependent [31].

The ACE2 exits in two forms: The first is as a type I membrane protein anchored to the plasma membrane through a transmembrane domain near de $\mathrm{C}$ terminus (ACE2 mRNA expression). The second is as a soluble enzyme lacking the transmembrane and cytosolic domains, also known as the soluble catalytic ectodomain of ACE2, that can be found in the plasma and other body fluids (Soluble ACE2 plasma activity) [26].
Fig. 1 ACE2 pathway. ACE2 is $>300$ times effective to converts Ang II to Ang 1-7 that for converts Ang I to Ang 1-9, which in the presence of NEP or ACE can converts Ang I and Ang 1-9 to Ang 1-7. ACE2 membrane-anchored protein at the catalytically active ectodomain undergoes shedding by the ADAM17, forming a soluble form of ACE2. ACE angiotensin-converting enzyme, ACE2 angiotensin-converting enzyme 2, Ang angiotensin, NEP neprilysin, PCP prolylcarboxypeptidase, ADAM17 disintegrin and metalloproteinase domain-containing protein 17 , Zn metalloproteinase zincbinding site
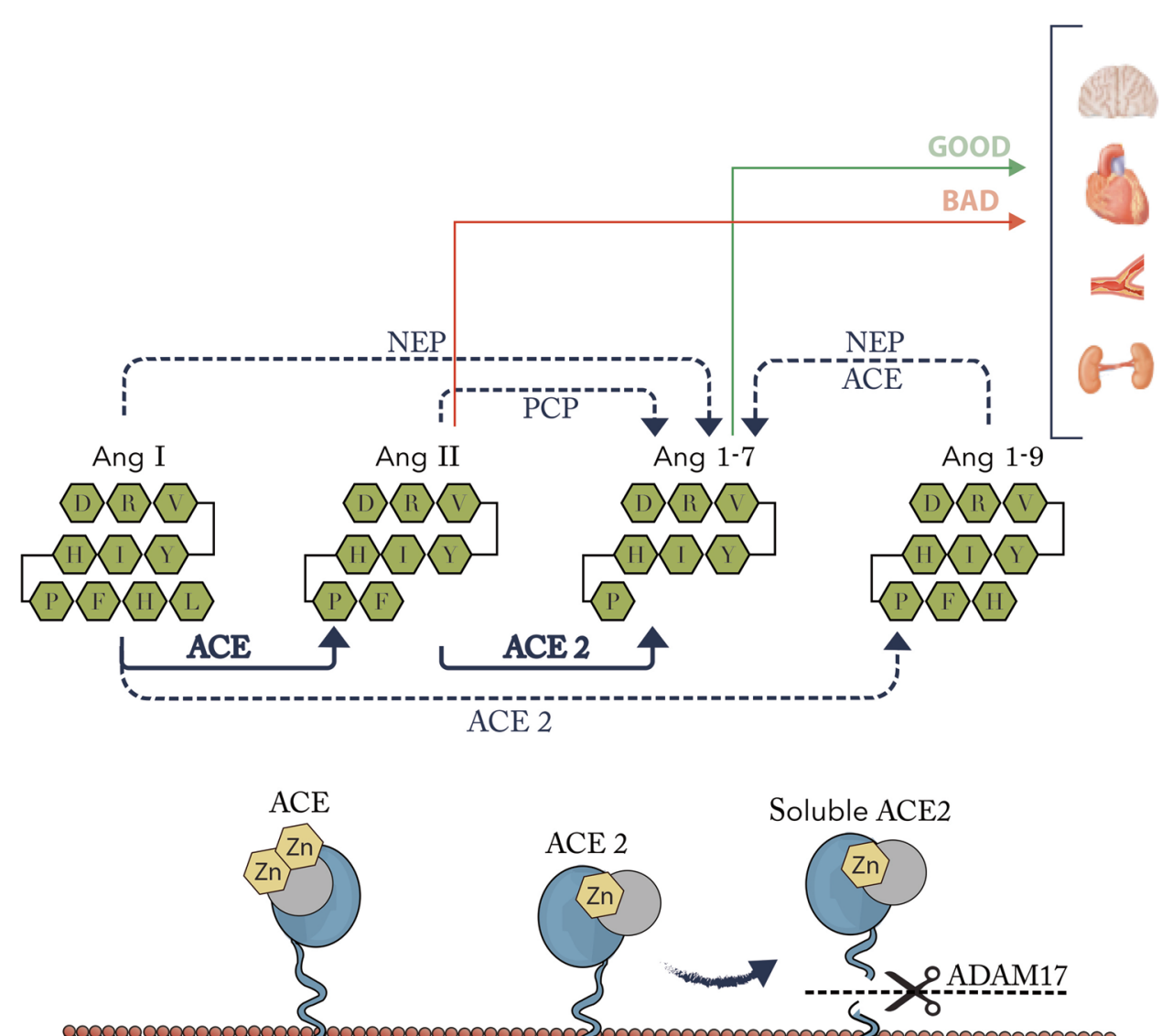

Soluble ACE2

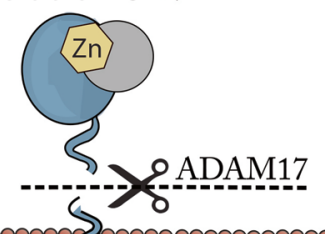

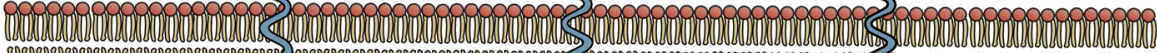

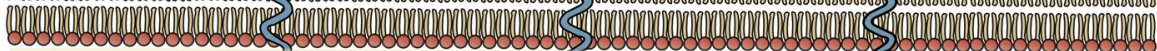

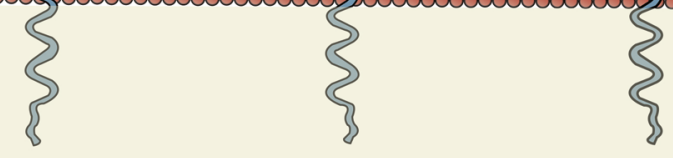




\section{The ACE2 biochemical functions}

ACE2 hydrolyses the carboxy-terminal leucine of the angiotensin I (AT1) to generate angiotensin 1-9 (AT1-9), which is converted to smaller angiotensin peptides by ACE. ACE2 can also cleave des-Arg bradykinin, neurotensin, angiotensin II (AT2), AT1, apelin-13, beta-casomorphin, dynorphin A 1-13, and ghrelin, but not bradykinin or 15 other vasoactive and hormonal peptides tested. ACE2 catalytic efficiency for AT2 is $>300$ times that for AT1. ACE functions as a dipeptidase whereas ACE2 as a carboxypeptidase $[27,32]$. On the other hand, ACE2 activity is unaffected by $10 \mu \mathrm{M}$ lisinopril, enalaprilat, or captopril, but activity was completely inhibited by $10 \mu \mathrm{M}$ of calcium ethylenediaminetetraacetic acid (EDTA) [26].

ACE2 mRNA expression in higher in kidney, heart, testis, and moderate levels in the ovary, colon, and small intestine [26] The ACE2 is expressed in the luminal surface of differentiated small intestinal epithelial cells and is a regulator of dietary amino acid homeostasis and gut microbial ecology [33]. ACE2 mRNA is also localised to the endothelium of intramyocardial vessels, medium-sized coronary arteries, and a lesser extent in vascular smooth muscle cells [27]. ACE2 expression is increased in alveolar type II cells [34]. Moreover, ACE2 is expressed at the apical surface of airway epithelia [35].

Pre-clinical studies indicated that ACE2 plays an important role in the thrombogenic activity. Fraga-Silva et al. showed that higher thrombus formation in vessels was associated with lower ACE2 activity and the lower ratio between ACE2/ACE activity. Besides, treatment with small-molecule Xanthenone ACE2 activator reduced platelet attachment to vessels and thrombus area by $60 \%$, whereas the time for thrombus formation was prolonged by $45 \%$ [36]. ACE2-catalyzed hydrolysis of AT2 produces Angiotensin 1-7 (AT1-7) [32]. AT2 is associated with an increase in the production and secretion of plasminogen activator- inhibitor type 1 from endothelial and smooth muscle cells and an augmentation of tissue factor expression, thereby enhancing the activity of the coagulation system. Moreover, AT2-mediated large vessel thrombosis involves activation of angiotensin II receptor type 1 (AT2r1), whereas the AT2-mediated microvascular thrombosis involves the activation of angiotensin II receptor type 2 (AT2r2) [37]. On the other hand, AT1-7 induced substantial nitric oxide production from platelets. It produced a potent inhibition of thrombus formation in Mas positive cells, whereas this effect was abolished in Mas negative cells. Also, bleeding time was decreased in Mas negative cells [38]. Moreover, AT1-7 activates endothelial nitric oxide synthase through an Akt-dependent mechanism and attenuates NADPH oxidase via the Mas receptor, providing an important role in maintaining endothelial function and vascular integrity [39]. Therefore, the ACE2/AT1-7/mas receptor axis exerts anti-thrombotic effects.
The soluble catalytic ectodomain of ACE2 plasma activity (Soluble ACE2)

In recent years, some studies demonstrated that increasing soluble catalytic ectodomain of ACE2 plasma activity also known as soluble ACE2 is associated with the clinical diagnosis of heart failure (HF) moreover correlated with worsening New York Heart Association (NYHA) functional class, increasing B-type natriuretic peptide levels and is associated to all-cause mortality [40, 41]. Similarly, the increasing soluble ACE2 has been found in patients with both ischemic and nonischemic cardiomyopathies and also in patients with clinical HF but a preserved left ventricular ejection fraction [40]. Furthermore, in patients with aortic stenosis, the elevated soluble ACE2 was an independent predictor of all-cause mortality with a hazard ratio (HR) of $2.28(1.03-5.06, p=0.042)$; increased soluble ACE2 was associated with reduced myocardial ACE2 gene expression (0.7-fold, $p=0.033)$ and severe myocardial fibrosis $(p=0.027)$ [42]. This suggests that the presence of circulating soluble ACE2 in plasma indicates the cause or effect of an adaptive or maladaptive physiological process operating in HF and cardiovascular diseases. Moreover, the higher soluble ACE2 activity is associated with diminished exercise capacity and correlates with elevated plasma asymmetric dimethylarginine a marker of oxidative stress-mediated endothelial dysfunction in patients with chronic systolic HF [43]. On the other hand, in the Finnish Diabetic Nephropathy Study (FinnDiane) using patients with type 1 diabetes $(n=859)$ and healthy controls $(n=204)$, the soluble ACE2 increases in patients with type 1 diabetes and vascular complications such as albuminuria and coronary artery disease (CAD) [44]. Moreover, in ST-elevation myocardial infarction (STEMI) patients, elevated soluble ACE2 correlated with infarct size $(r=0.373, p<0.001)$ and is associated with the occurrence of left ventricular remodelling (OR 4.4, $1.3-15.2, p=0.027$ ) [45]. Similarly, patients with angiographically CAD, high soluble ACE2 was a predictor of major adverse cardiovascular events (MACE) with HR 2.4 $(1.24-4.72, p=0.009)$ [46]. In addition, the soluble ACE2 is increased in atrial fibrillation (AF) and is associated to left atrial (LA) electroanatomic mapping parameters of low mean LA bipolar voltage $(\mathrm{R} 2=0.22, p=0.03)$, a high proportion of complex fractionated electrocardiograms $(\mathrm{R} 2=0.32, p=0.009)$, and long LA activation time $\left(R^{2}=0.2, p=0.04\right)$ which reflects a more advance LA structural remodelling [47]. These studies indicated that the ectodomain shedding of ACE2 plays an important role in the process of early cardiac remodelling (Table 1) and their cut-off values of soluble ACE2 could provide new insight for a biomarker of cardiac remodelling. Hence, the 


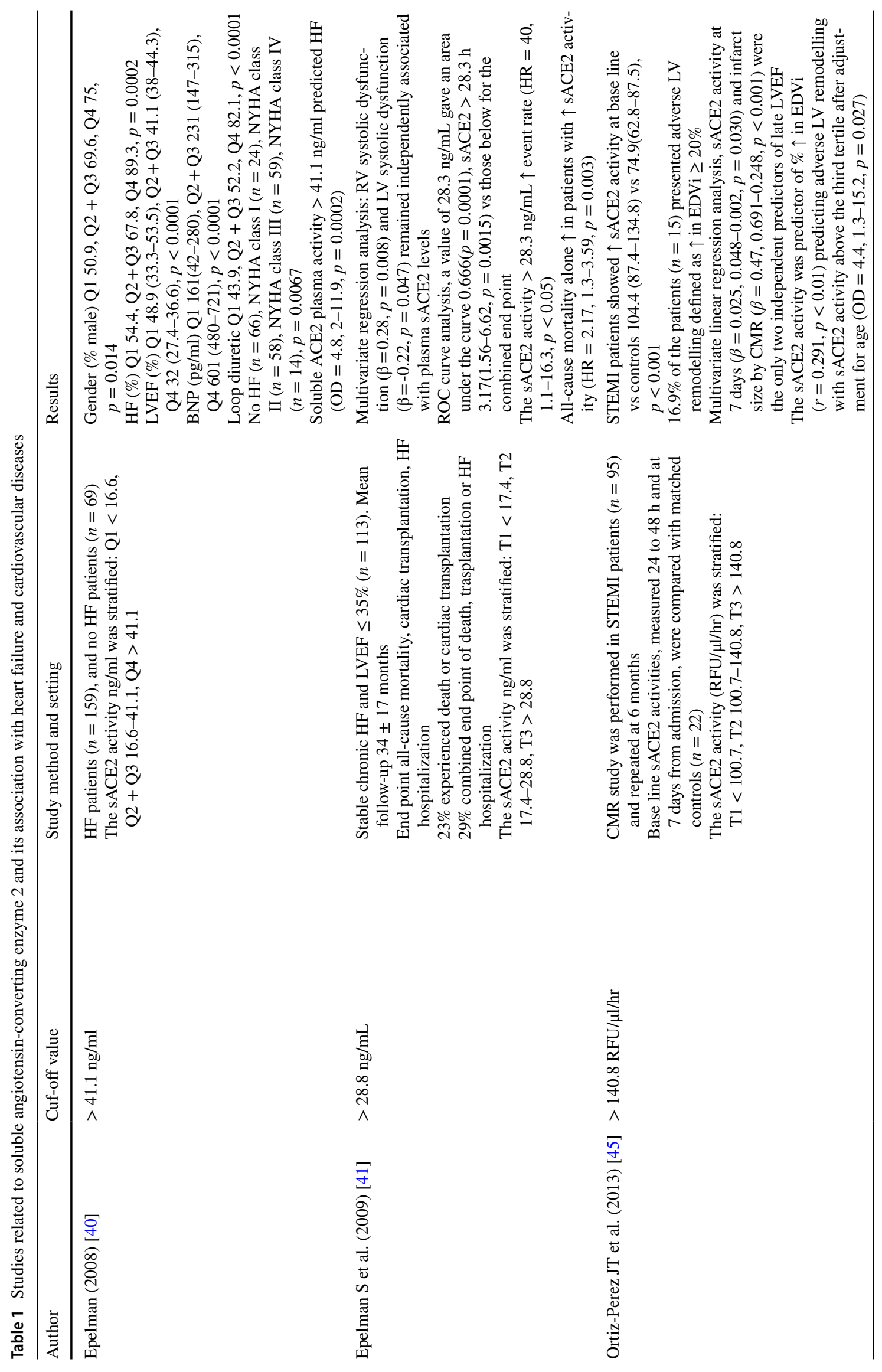




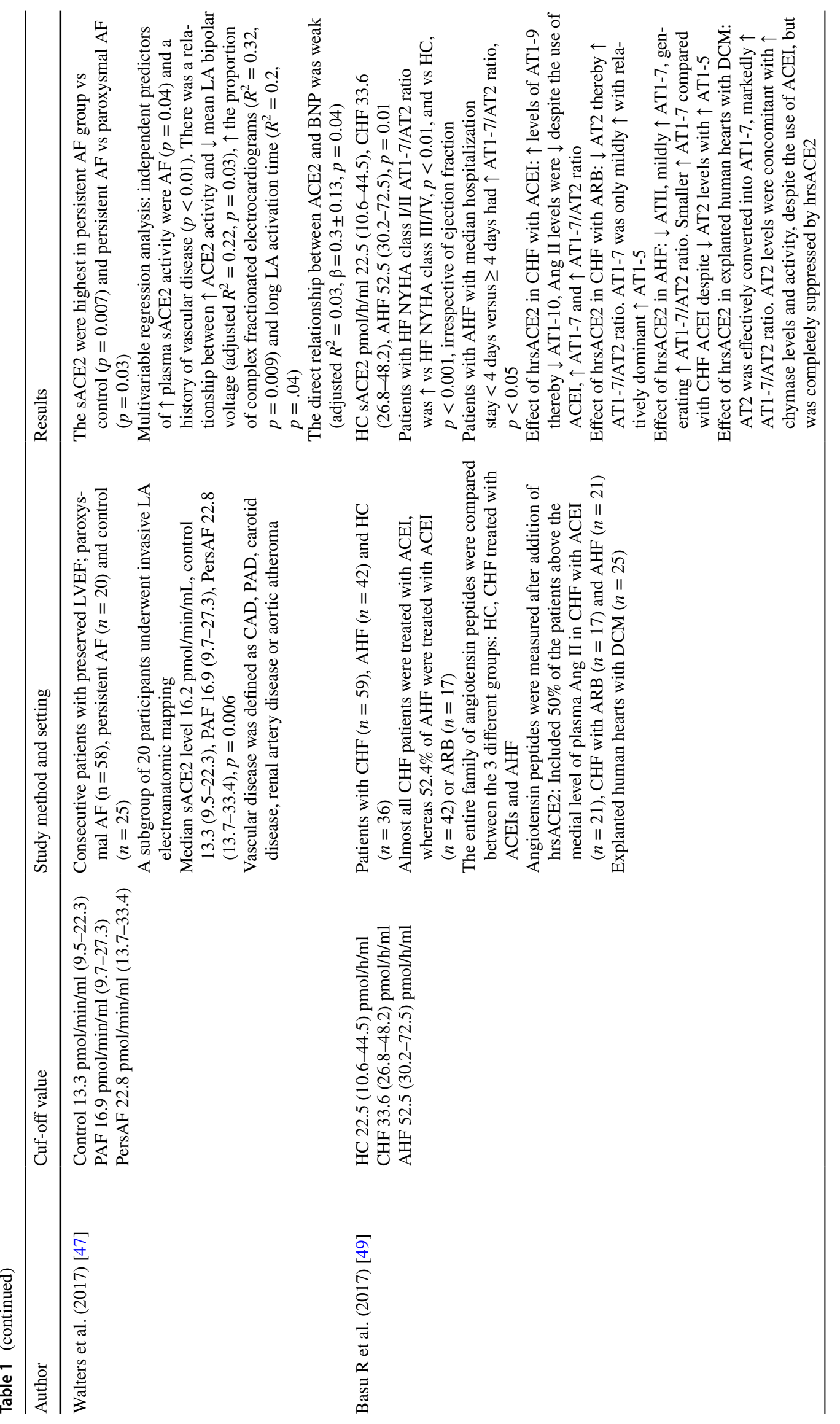




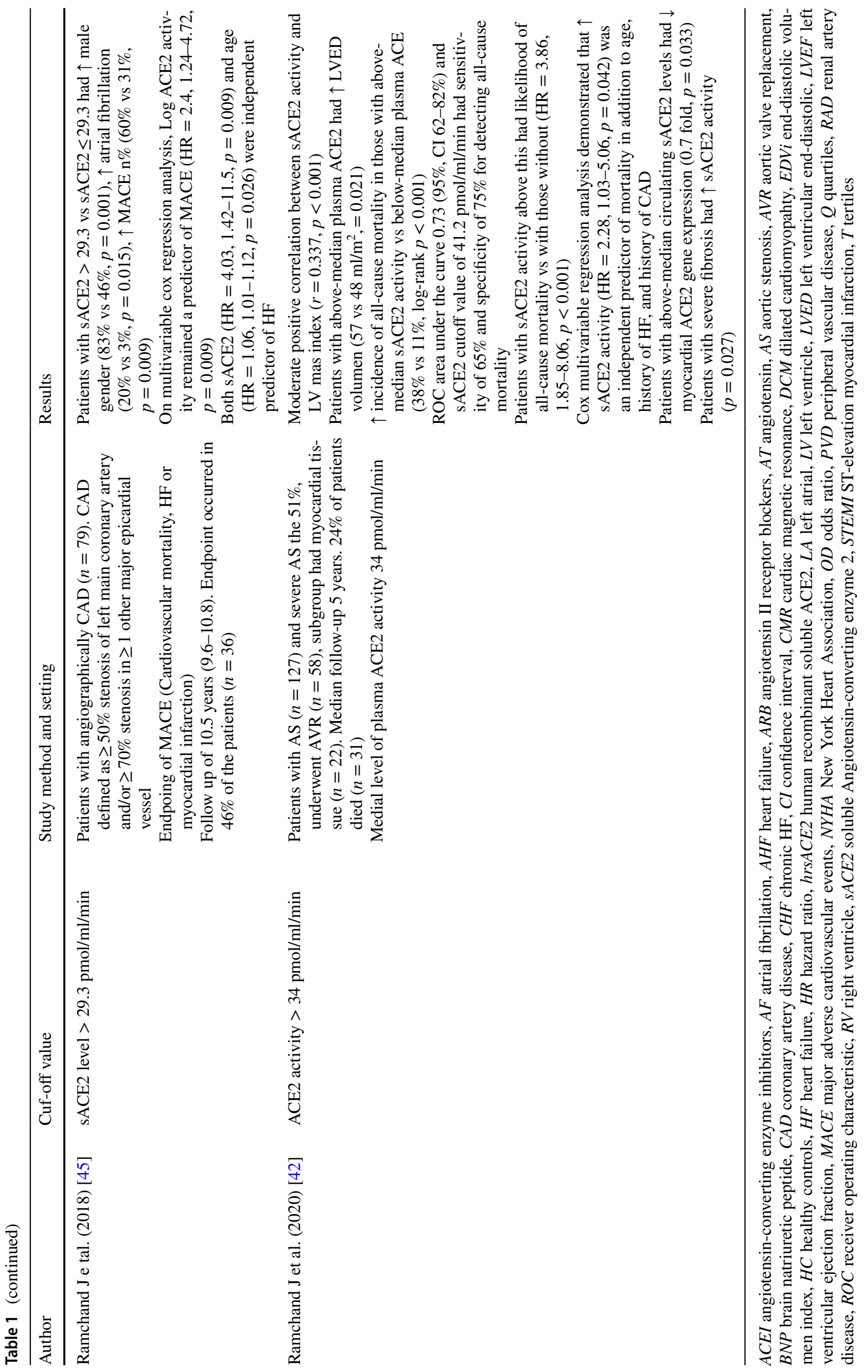


human soluble ACE2 exerts an effect in the ACE2/angiotensin 1-7 axis modulation in heart failure, cardiovascular disease, and lung injury and currently, is a potential approach for SARS-COV-2 infection therapy.

\section{The human recombinant soluble ACE2}

Healthy human subjects well tolerate doses of 100-1200 $\mu \mathrm{g} /$ $\mathrm{kg}$ of a recombinant version of the catalytic ectodomain of human ACE2, also known as the human recombinant soluble ACE2 (hrsACE2). The dose was given as an intravenous infusion over 30 min and had a terminal half-life of about $10 \mathrm{~h}$ [48]. Basu R et al. measured the entire family of angiotensin peptides in patients with HF. After administration of hrsACE2 effectively normalised elevated AT2 while increasing AT1-7 and AT1-9 in patients with HF. Interestingly, the effect of hrsACE2 in the subgroup of chronic heart failure (CHF) treated with ARB compared with CHF treated with ACEI, the AT2 was lowered thereby increasing AT1-7/AT2 ratio but the AT1-7 was only mildly increased with relatively dominant increased in plasma Angiotensin 1-5 (AT15). Therefore, ACEI reduced AT1-7 degradation, whereas hrsACE2 increased AT1-7 formation [49]. AT1-7 has a very short half-life $(<9 \mathrm{~s})$, and release of a soluble ectodomain of ACE2 from the vascular endothelium may serve to alter systemic AT1-7 concentrations and the relative peripheral balance of ACE2/ACE [40]. In contrast, a small study of patients with acute respiratory distress syndrome showed that the AT2 was higher in nonsurvivors than in survivors, the use of hrsACE2 GSK2586881, 3 days of twice-daily infusions of $0.4 \mathrm{mg} / \mathrm{kg}$, was well-tolerated and decreased AT2 level concentration, whereas AT1-7, AT1-5, and surfactant protein D concentrations were increased [50]. Hence, the ACE2/AT1-7/mas axis exerts cardiovascular protection providing anti-fibrotic, anti-hypertrophic, anti-oxidant, and vasodilator effects. In contrast, ACE/AT2/Angiotensin 1 receptor (AT1R) axis exerts the opposite effect providing fibrosis, hypertrophy, endothelial injury, and vasoconstriction [51].

\section{ACE2 catalytic ectodomain as the functional receptor for the SARS-CoV-2}

The envelope-embedded surface-located spike glycoprotein (S) of SARS-CoV-1 attaches the virus to it is cellular receptor ACE2 [52]. SARS-CoV-2 share 79.6\% sequence identity to SARS-CoV-1 and uses the same cell entry receptor ACE2 [19]. Structural analysis of ACE2 has revealed the presence of a single catalytic domain that is located in the ectodomain was identified as a functional receptor for SARS-CoV-1, and the ectodomain is indispensable to viral attachment through a defined RBD on $\mathrm{S}$ mediates this interaction [53]. A recent structural analysis demonstrated that $\mathrm{S}$ subunit 1 (S1) and the C-terminal domain of the SARS-CoV-2, otherwise known as the RBD, bound to soluble ectodomain protein of human ACE2 with fourfold higher binding affinity compared with the SARS-CoV-1 RBD. Hence, SARS-COV-2 C-terminal domain utilises its external subdomain to recognise subdomain I of the ectodomain protein of human ACE2 [15]. Furthermore, a study in vitro demonstrated that hrsACE2 inhibits the attachment of the SARS-CoV-2 to the cells; this inhibition was dependent on the initial quantity of the virus in the inoculum and the dose of hrsACE2, establishing dose-dependency. Therefore, hrsACE2 blocks early entry of SARS-CoV-2 infections in host cells [54]. SARS-CoV-1 and SARS-CoV-2 bind to ACE2 ectodomain catalytic site receptor, with the subsequent membrane fusion and virus entry into the cell, leads to down-regulation of these receptors. This ACE2 down-regulation induced by the cell entry of the virus may be particularly detrimental in patients with preexisting ACE2 deficiency due, for example, to older age, diabetes, hypertension, and prior cardiovascular disease [56]. Also, these factors were associated with developed ARDS in the cohorts of Wuhan and Lombardy [18, 55]. Therefore, in the setting of enhanced ACE2 deficiency produced by the viral invasion, the marked dysregulation of the ACE2/ AT1-7/Mas axis would contribute to enhancing the progression of inflammatory and thrombotic processes [56].

\section{Disruption of the catalytic ectodomain of the ACE2: a potential approach for SARS-CoV-2 infection therapy?}

A novel hrsACE2 with a fragment crystallisable region (Fc) domain of human immunoglobulin IgG1 (ACE2-Ig) and ACE2 variant $(\mathrm{HH} / \mathrm{NN})$ in which two active-site histidine residues (amino acids 374 and 378) had been altered to asparagine residues to reduce the catalytic activity (mACE2-Ig), both have high-affinity binding to the receptor-binding domain and neutralised virus pseudotyped with SARS-CoV-1 or SARS-CoV-2 spike proteins in vitro [57]. On the other hand, ACE2 activity is unaffected by $10 \mu \mathrm{M}$ of ACEI, but activity was completely inhibited by $10 \mu \mathrm{M}$ of EDTA. This reinforces the proposition that ACE2 is a metalloprotease, but with a distinct substrate and inhibitor specificity from ACE. Hence, chelating agents such as EDTA removes zinc, which is essential for activity and leads to complete inactivation [26]. EDTA is chelator approved by the US Food and Drug Administration to treat lead poisoning. The Trial to Assess Chelation Therapy (TACT) study demonstrated that $3 \mathrm{~g}$ of EDTA intravenous weekly had shown a safety profile in patients with ischemic cardiomyopathy $[58,59]$. It is known so far that the ACE2 
ectodomain subdomain I contain the single catalytic domain composed of the metalloprotease zinc-binding site (amino acids 374-378, HEMGH) and structural analysis has demonstrated that SARS-CoV-2 uses this ectodomain catalytic site receptor for viral attachment $[15,53]$. Therefore, EDTA chelation therapy could be a potential approach for SARS-CoV-2 infection therapy.

\section{Conclusion}

The ACE2 is a type I integral membrane that was discovered two decades ago. The ACE2 exists as a transmembrane protein (ACE2 mRNA expression) and as a soluble catalytic ectodomain of ACE2 also known as the soluble ACE2 that can be found in plasma and other body fluids (ACE2 plasma activity). Moreover, many studies have shown that the soluble ACE2 plasma activity is associated with an adverse cardiac remodelling in heart failure and cardiovascular diseases, as well as a prognostic marker of cardiovascular mortality and all-cause mortality. Therefore, the ectodomain shedding of ACE2 plays a role in the process of cardiac remodelling. However, the presence of circulating soluble ACE2 in plasma indicates either the cause or effect of an adaptive or maladaptive physiologic process operative in HF and cardiovascular diseases. The hrsACE2 exerts an effect in the ACE2/AT1-7 axis modulation in HF, cardiovascular disease, and lung injury and currently, is a potential approach for SARS-COV-2 infection therapy. On the other hand, chelating agents such as EDTA disrupts the catalytic ectodomain of the ACE2, and the SARS-CoV-2 uses this ectodomain catalytic site receptor for viral attachment. Hence, EDTA chelation therapy could be a potential approach for SARSCoV-2 infection therapy. Nevertheless, more research is required for a better understanding of the physiology of the soluble ACE2 for potential applications in SARS-CoV-2 infection and heart failure, providing an early diagnosis of cardiac remodelling, prognosis and therapeutic approaches.

\section{References}

1. Zhu N, Zhang D, Wenling W, Li X, Yang B, Song J, Zhao X, Huang B, Shi W, Lu R, Niu P, Zhan F, Ma X, Wang D, Xu W, Gao GF, Tan W et al (2019) A Novel Coronavirus from patients with Pneumonia in China, N Engl J Med 382(8):727-733. https:// doi.org/10.1056/NEJMoa2001017. https://pubmed.ncbi.nlm.nih. gov/31978945/

2. Gorbalenya AE, Baker SC, Baric RS, Groot RJ, Drosten C, Gulyaeva AA, Haagmans BL, Lauber C, Leontovich AM, Neuman BW, Penzar D, Perlman S, Poon LLM, Samborskiy DV, Sidorov IA, Sola I, Ziebuhr J et al (2020) The species Severe acute respiratory syndrome-related coronavirus: classifying 2019-nCov and naming it SARS-CoV-2. Nat Microbiol 5, 536-544 https:// pubmed.ncbi.nlm.nih.gov/32123347/
3. Lu G, Liu D (2020) SARS-like Virus in the Middle East: A Truly Bat-Related Coronavirus Causing Human Diseases. Protein Cell 3(11):803-5. https://doi.org/10.1007/s13238-012-2811-1 https://pubmed.ncbi.nlm.nih.gov/23143870/

4. World Health Organization. Rolling updates on coronavirus disease (COVID-19). 2020 (https://www.who.int/emergencies/diseases/ novel-coronavirus-2019/events-as-they-happen).

5. https://www.cdc.gov/coronavirus/2019-ncov/hcp/therapeuticoptions.html

6. Colson P, Rolain JM, Raoult D et al (2020) Chloroquine for the 2019 novel coronavirus SARS-CoV-2. Int J Antimicrob Agents 105923. https://pubmed.ncbi.nlm.nih.gov/32070753/

7. Yao X, Ye F, Zhang M, Cui C, Huang B, Niu P, Liu X, Zhao L, Dong E, Song C, Zhan S, Lu R, Li H, Tan W, Liu D et al (2020) In vitro antiviral activity and projection of optimized dosing design of hydroxychloroquine for the treatment of severe acute respiratory syndrome coronavirus 2 (SARS-CoV-2). Clin Infect Dis ciaaa237. https://doi.org/10.1093/cid/ciaa237. https://pubmed. ncbi.nlm.nih.gov/32150618/

8. Gautret P, Lagier JC, Parola P, Hoang VT, Meddeb L, Mailhe M, Doudier B, Courjon J, Giordanengo V, Vieira VE, Dupont HT, Honore S, Colson P, Chabriere E, Scola B, Rolain J, Brouqui P, Raoult D et al (2020) Hydroxychloroquine and azithromycin as a treatment of COVID-19: results of an open-label non-randomized clinical trial. Int J Antimicrob Agents 105949. https://pubmed. ncbi.nlm.nih.gov/32205204/

9. Rosenberg ES, Dufort EM, Udo T, Wilberschied LA, Kumar J, Tesoriero J, Weinberg P, Kirkwood J, Muse A, DeHovitz J, Blog DS, Hutton B, Holtgrave DR, Zucker HA et al (2020) Association of treatment with hydroxychloroquine or azithromycin with in-hospital mortality in patients with COVID-19 in New York State. JAMA 11:e208630. https://doi.org/10.1001/jama.2020.8630. https:// pubmed.ncbi.nlm.nih.gov/32392282/

10. Wang M, Cao R, Zhang L, Yang X, Liu J, Xu M, Shi Z, Hu Z, Zhong W, Xiao G (2020) Remdesivir and chloroquine effectively inhibit the recently emerged novel coronavirus (2019-nCOV) in vitro. Cell Res (3):269-271. https://doi.org/10.1038/s41422020-0282-0. https://pubmed.ncbi.nlm.nih.gov/32020029/

11. Wang Y, Zhang D, Du Guanhua, Du R, Zhao J, Jin Y, Fu S, Gao L, Cheng Z, Lu Q, Hu Y, Luo G, Wang K, Lu Y, Li H, Wang S, Ruan S, Yang C, Mei C, Wang Y, Ding D, Wu F, Tang X, Ye X, Ye Y, Liu B, Yang J, Yin W, Wang A, Fan G, Zhou F, Liu Z, Gu X, Xu J, Shang L, Zhang Y, Cao L, Guo T, Wan Y, Qin H, Jiang Y, Jaki T, Hayden FG, Horby PW, Cao B, Wang C et al (2020) Remdesivir in Adults with severe COVID-19: a randomised, double-blind, placebo-controlled, multicentre trial. Lancet https:// doi.org/10.1016/S0140-6736(20)31022-9

12. Cao B, Wang Y, Wen D, Liu W, Wang J, Fan G, Ruan L, Song B, Cai Y, Wei M, Li X, Xia J, Chen N, Xiang J, Yu T, Bai T, Xie X, Zhang L, Li C, Yuan Y, Chen H, Li H, Shang L, Wang K, Li K, Zhou X, Dong X, Qu Z, Lu S, Hu X, Ruan S, Luo S, Wu J, Peng L, Cheng F, Pan L, Zou J, Jia C, Wang J, Liu X, Wang S, Wu X, Ge Q, He J, Zhan H, Qiu F, Guo L, Huang C, Jaki T, Hayden FG, Horby PW, Zhang D, Wang $\mathrm{C}$ et al (2020) A Trial of Lopinavir-Ritonavir in Adults Hospitalized with Severe Covid-19. N Engl J Med 382(19):1787-1799. https:// pubmed.ncbi.nlm.nih.gov/32187464/

13. Shen C, Wang Z, Zhao F, Yang Y, Li J, Yuan J, Wang F, Li D, Yang M, Xing L, Wei J, Xiao H, Yang Y, Qu J, Qing L, Chen L, Xu Z, Peng L, Li Y, Zheng H, Chen F, Huang K, Jiang Y, Dongjing L, Zhang Z, Liu Y, Liu L et al (2020) Treatment of 5 critically ill patients with COVID-19 with convalescent plasma. JAMA 323(16):1582-1589. https://doi.org/10.1001/ jama.2020.4783. https://pubmed.ncbi.nlm.nih.gov/32219428/

14. Zeng Q, Yu Z, Gou J, Li G, Ma S, Zhang G, Xu J, Lin W, Cui G, Zhang M, Li C, Wang Z, Zhang Z, Liu Z et al (2020) Effect of convalescent plasma therapy on viral shedding and survival in 
COVID-19 patients. J Infect Dis jiaa228. https://doi.org/10.1093/ infdis/jiaa228. https://pubmed.ncbi.nlm.nih.gov/32348485/

15. Wang Q, Zhang Y, Wu L, Niu S, Song C, Zhang Z, Lu G, Qiao C, Hu Y, Yuen K, Wang Q, Zhou H, Yan J, Qi J et al (2020) Structural and functional basis of SARS-CoV-2 entry by using human ACE2. Cell 181(4):894-904.e9. https://doi.org/10.1016/j. cell.2020.03.045. https://pubmed.ncbi.nlm.nih.gov/32275855/

16. Sanders JM, Monogue ML, Jodlowski TZ, Cutrell JB et al (2020) Pharmacologic Treatments for Coronavirus Disease 2019 (COVID-19): A Review. JAMA. https://doi.org/10.1001/ jama.2020.6019 https://pubmed.ncbi.nlm.nih.gov/32282022/

17. Krammer F (2020) SARS-CoV-2 vaccines in development. Nature 586(7830):516-527. https://doi.org/10.1038/s41586-020-2798-3. https://pubmed.ncbi.nlm.nih.gov/32967006/

18. Wu C, Chen X, Cai Y, Xia J, Zhou X, Xu S, Huang H, Zhang L, Zhou X, Du C, Zhang Y, Song J, Wang S, Chao Y, Yang Z, Xu J, Zhou X, Chen D, Xiong W, Xu L, Zhou F, Jiang J, Bai C, Zheng J, Song Y et al (2020) Risk factors associated with acude respiratory distress syndrome and death in patients with coronavirus disease 2019 pneumonia in Wuhan, China. JAMA Intern Med. https://doi. org/10.1001/jamainternmed.2020.0994. https://pubmed.ncbi.nlm. nih.gov/32167524/

19. Zhou P, Yang XL, Wang XG, Hu B, Zhang L, Zhang W, Si H, Zhu Y, Li B, Huang C, Chen H, Chen J, Luo Y, Guo H, Jiang R, Liu M, Chen Y, Shen X, Wang X, Zheng X, Zhao K, Chen Q, Deng F, Liu L, Yan B, Zhan F, Wang Y, Xiao G, Shi Z et al (2020) A pneumonia outbreak associated with a new coronavirus of probable bat origin. Nature 579(7798):270-273. https://pubmed.ncbi. nlm.nih.gov/32015507/

20. Ferrario CM, Jessup J, Chappell MC, Averill DB, Brosnihan KB, Tallant EA, Diz DI, Gallagher PE (2005) Effect of angiotensin-converting enzyme inhibition and angiotensin II receptor blockers on cardiac angiotensin-converting enzyme 2. Circulation 111(20):2605-10. https:// doi.org/10.1161/CIRCULATIONAHA.104.510461. https://pubmed. ncbi.nlm.nih.gov/15897343/

21. Ishiyama Y, Gallagher PE, Averill DB, Tallant EA, Brosnihan KB, Ferrario CM (2004) Upregulation of angiotensin-converting enzyme 2 after myocardial infarction by blockade of angiotensin II receptors. Hypertension 43(5):970-6. https://doi.org/10.1161/01. HYP.0000124667.34652.1a. https://pubmed.ncbi.nlm.nih. gov/15007027/

22. Fang LK, Karakiulakis G, Roth M et al (2020) Are patients with hypertension and diabetes mellitus at increased risk for COVID19 infection? Lancet Respir Med (4):e21. https://doi.org/10.1016/S22132600(20)30116-8. https://pubmed.ncbi.nlm.nih.gov/32171062/

23. Bavishi C, Maddox TM, Messerli FH et al (2020) Coronavirus disease 2019 (COVID-19) infection and renin angiotensin system blockers. JAMA Cardiol. https://doi.org/10.1001/jamacardio.2020.1282. https:// pubmed.ncbi.nlm.nih.gov/32242890/

24. Mancia G, Rea F, Ludergnani M, Apolone G, Corrao G et al (2020) Renin-angiotensin-aldosterone system blockers and the risk of Covid-19. N Engl J Med NEJMoa2006923. https:// doi.org/10.1056/NEJMoa2006923. https://pubmed.ncbi.nlm.nih. gov/32356627/

25. Reynolds HR, Adhikari S, Pulgarin $\mathrm{C}$, Troxel AB, Iturrate E, Johnson SB, Hausvater A, Newman JD, Berger JS, Bangalore S, Katz SD, Fishman GI, Kunichoff D, Chen Y, Ogedegbe G, Hochman JS et al (2020) Renin-angiotensinaldosterone system inhibitors and risk of Covid-19. N Engl J Med NEJMoa2008975. https://doi.org/10.1056/NEJMoa2008975. https:// pubmed.ncbi.nlm.nih.gov/32356628/

26. Tipnis SR, Hooper NM, Hyde R, Karran E, Christie G, Turner AJ et al (2000) A human homolog of angiotensin-converting enzyme: Cloning and function- al expression as a captoprilinsensitive carboxypeptidase. J Biol Chem 275:33238-43 https:// pubmed.ncbi.nlm.nih.gov/10924499/
27. Donoghue M, Hsieh F, Baronas E, Godbout K, Gosselin M, Stagliano N, Donovan M, Woolf B, Robison K, Jeyaseelan R, Breitbart E, Acton $S$ et al (2000) A novel angiotensin-convert- ing enzyme-related carboxypeptidase (ACE2) converts angiotensin I to an- giotensin 1-9. Circ Res 87:E1-E9. https://pubmed.ncbi.nlm. nih.gov/10969042/

28. Towler P, Staker B, Prasad SG, Menon S, Tang J, Parsons T, Ryan D, Fisher M, Williams D, Dales N.A, Patane MA, Pantoliano MW et al (2004) ACE2 X-ray structures reveal a large hingebending motion important for inhibitor binding and catalysis. J Biol Chem 279(17);17996-8007. https://pubmed.ncbi.nlm.nih. gov/14754895/

29. Iwata M, Silva Enciso JE, Greenberg BH et al (2009) Selective and specific regulation of ectodomain shedding of angiotensinconverting enzyme 2 by tumor necrosis factor alpha-converting enzyme. Am J Physiol Cell Physiol 297(5):C1318-29. https:// pubmed.ncbi.nlm.nih.gov/19759332/

30. Jia HP, Look DC, Tan P, Shi L, Hickey M, Gakhar L, Chappell MC et al (2009) Wohlford-Lenane C, McCray Jr P.B. Ectodomain shedding of angiotensin converting enzyme 2 in human airway epithelia. Am J Physiol Lung Cell Mol Physiol 297(1):L84-96. https://pubmed.ncbi.nlm.nih.gov/19411314/

31. Lambert DW, Clarke NE, Hooper NM, Turner AJ et al (2008) Calmodulin interacts with angiotensin-converting enzyme-2 (ACE2) and inhibits shedding of its ectodomain. FEBS Lett 582(2):385-90. https://doi.org/10.1016/j.febslet.2007.11.085. Epub 2007 Dec 10. https://pubmed.ncbi.nlm.nih.gov/18070603/

32. Vickers C, Hales P, Kaushik V, Dick L, Gavin J, Tang J, Godbout K, Parsons T, Baronas E, Hsieh F, Acton S, Patane M, Nichols A, Tummino $P$ et al (2002) Hydrolysis of biological peptides by human angiotensin-converting enzyme-related carboxypeptidase. J Biol Chem 277(17):14838 43. https://pubmed.ncbi.nlm.nih. gov/11815627/

33. Hashimoto T, Perlot $\mathrm{T}$, Rehman A, Trichereau J, Ishiguro $\mathrm{H}$, Paolino M, Sigl V, Hanada T, Hanada R, Lipinski S, Wild B, Camargo SMR, Singer D, Richter A, Kuba K, Fukamizu A, Schreiber S, Clevers H, Verrey F, Rosenstiel P, Penninger JM et al (2012) ACE2 links amino acid malnutrition to microbial ecology and intestinal inflammation. Nature 487(7408):477-81. https:// pubmed.ncbi.nlm.nih.gov/22837003/

34. Qian Z, Travanty EA, Oko L, Edeen K, Berglund A, Wang J, Ito Y, Holmes KV, Mason RJ et al (2013) Innate Immune Response of Human Alveolar Type II Cells Infected with Severe Acute Respiratory Syndrome-Coronavirus. Am J Respir Cell Mol Biol 48(6):742-748. https://pubmed.ncbi.nlm.nih.gov/23418343/

35. Jia HP, Look DC, Hichey $M$ et al (2006) Infection of human airway epithelia by SARS coronavirus is associated with ACE2 expression and localization. Adv Exp Med Biol 581:479-484

36. Fraga-Silva RA, Sorg B, Wankhede M, Dedeugd C, Jun JY, Baker MB, Li Y, Castellano RK, Katovich MJ, Raizada MK, Ferreira AJ et al (2010) ACE2 Activation promotes antithrombotic activity. Mol Med 16(5-6):210-215. https://pubmed.ncbi.nlm.nih. gov/20111697/

37. Senchenkova EY, Russell J, Almeida-Paula LD, Harding JW, Granger DN et al (2010) Angiotensin II-mediated microvascular thrombosis. Hypertension 56(6):1089-95. https://doi.org/10.1161/ HYPERTENSIONAHA.110.158220. https://pubmed.ncbi.nlm. nih.gov/20975035/

38. Fraga-Silva RA, Pinheiro SV, Goncalves AC, Alenina N, Bader M, Santos RA et al (2008) The antithrombotic effect of angiotensin-(1-7) involves mas-mediated NO release from platelets. Mol Med 14(1-2):28-35. https://doi.org/10.2119/200700073. https://pubmed.ncbi.nlm.nih.gov/18026570/

39. Sampaio WO, Souza dos Santos RA, Faria-Silva R, da Mata Machado LT, Schiffrin EL, Touyz RM et al (2007) Angiotensin-(1-7) through receptor mas mediates endothelial 
nitric oxide synthase activation via Akt-dependent pathways. Hypertension 49(1):185-92. https://doi.org/10.1161/01. HYP.0000251865.35728.2f. https://pubmed.ncbi.nlm.nih. gov/17116756/

40. Epelman S, Tang WH, Chen SY, Lente FV, Francis GS, Sen S et al (2008) Detection of soluble angiotensin-converting enzyme 2 in heart failure: insights into the endogenous counter-regulatory pathway of the renin-angiotensin-aldosterone system. J Am Coll Cardiol 52(9):750-4. https://pubmed.ncbi.nlm.nih.gov/18718423/

41. Epelman S, Shrestha K, Troughton RW, Francis GS, Sen S, Klein AL, Tang WHW et al (2009) Soluble Angiotensin-Converting Enzyme 2 in Human Heart Failure: Relation With Myocardial Function and Clinical Outcomes. J Card Fail 15(7):565-71. https:// pubmed.ncbi.nlm.nih.gov/19700132/

42. Ramchand J, Patel SK, Kearney LG, Matalanis G, Farouque O, Srivastava PM, Burrell LM et al (2020) Plasma ACE2 activity predicts mortality in aortic stenosis and is associated with severe myocardial fibrosis. JACC Cardiovasc Imaging 13(3):655-664. https://pubmed.ncbi.nlm.nih.gov/31607667/

43. Shao Z, Schuster A, Borowski AG, Thakur A, Li L, Tang WHW et al (2019) Soluble angiotensin converting enzyme 2 levels in chronic heart failure is associated with decreased exercise capacity and increased oxidative stress-mediated endotelial dysfunction. Transl Res 212:8088. https://pubmed.ncbi.nlm.nih.gov/31323221/

44. Soro-Paavonen A, Gordin D, Forsblom C, Rosengard-Barlund M, Waden J, Thorn L, Sandholm N, Thormas MC, Groop P et al (2012) Circulating ACE2 activity is increased in patients with type 1 diabetes and vascular complications. J Hypertens 30(2):375-83. https://pubmed.ncbi.nlm.nih.gov/22179088/

45. Ortiz-Pérez JT, Riera M, Bosch X, Caralt TM, Perea RJ, Pascual J, Soler MJ et al (2013) Role of circulating angiotensin coverting enzyme 2 in left ventricular remodeling following myocardial infarction: a prospective controlled study. PLoS One 22;8(4):e61695. https://pubmed.ncbi.nlm.nih.gov/23630610/

46. Ramchand J, Patel SK, Srivastava PM, Farouque O, Burrell LM et al (2018) Elevated plasma angiotensin converting enzyme 2 activity is an independent predictor of major adverse cardiac events in patients with obstructive coronary artery disease. PLoS One 13(6):e0198144. https://pubmed.ncbi.nlm.nih.gov/29897923/

47. Walters TE, Kalman JM, Patel SK, Mearns M, Velkoska E, Burrell LM et al (2017) Angiotensin converting enzyme 2 activity and human atrial fibrillation: increased plasma angiotensin converting enzyme 2 activity is associated with atrial fibrillation and more advanced left atrial structural remodelling. Europace 19(8):12801287. https://pubmed.ncbi.nlm.nih.gov/27738071/

48. Haschke M, Schuster M, Poglitsch M, Loibner H, Salzberg M, Bruggisser M, Penninger J, Krahenbuhl S et al (2013) Pharmacokinetics and pharmacodynamics of recombinant human angiotensinconverting enzyme 2 in healthy human subjects. Clin Pharmacokinet 52(9):783-92. https://pubmed.ncbi.nlm.nih.gov/23681967/

49. Basu R, Poglitsch M, Yogasundaram H, Thomas J, Rowe BH et al (2017) Oudit G.Y. Roles of angiotensin peptides and recombinant human ACE2 in heart failure. J Am Coll Cardiol 69(7):805-819. https://pubmed.ncbi.nlm.nih.gov/28209222/

50. Khan A, Beenthin C, Zeno B, Albertson TE, Boyd J, Christie JD, Hall R, Poirier G, Ronco JJ, Tidswell M, Hardes K, Powley WM, Wright TJ, Siederer SK, Fairman DA, Lipson DA, Bayliffe AI, Lazaar AL et al (2017) A pilot clinical trial of recombinant human angiotensin-converting enzyme 2 in acute respiratory distress syndrome. Crit Care 21(1):234. https://pubmed.ncbi.nlm.nih. gov/28877748/
51. Patel VB, Zhong JC, Grant MB, Oudit GY et al (2016) Role of the ACE2/Angio 1-7 axis of the Renin-Angiotensin System in Heart Failure. Circ Res 118(8):1313-26. https://pubmed.ncbi.nlm.nih. gov/27081112/

52. Li W, Moore MJ, Vasilieva N, Sui J, Wong SK, Berne MA, Somasundaran M, Sullivan JL, Luzuriaga K, Greenough TC, Choe H, Farzan M et al (2003) Angiotensin-converting enzyme 2 is a functional receptor for the SARS coronavirus. Nature 426(6965):450-4. https://pubmed.ncbi.nlm.nih.gov/14647384/

53. Li F, Li W, Farzan M, Harrison SC et al (2005) Structure of SARS coronavirus spike receptor-binding domain complexed with receptor. Science 309:1864-1868. https://pubmed.ncbi.nlm.nih. gov/16166518/

54. Monteil V, Kwon H, Prado P, Hagelkruys A, Wimmer RA, Stahl M, Leopoldi A, Garreta E, Del Pozo CH, Prosper F, Romero JP, Wirnsberger G, Zhang H, Slutsky AS, Conder R, Montserrat N, Mirazimi A, Penninger JM et al (2020) Inhibition of SARSCoV-2 infections in engineered human tissues using clinicalgrade soluble human ACE2. Cell 181(4):905-913.e7. https://doi. org/10.1016/j.cell.2020.04.004. https://pubmed.ncbi.nlm.nih. gov/32333836/

55. Grasselli G, Zangrillo A, Zanella A, Antonelli M, Cabrini L, Castelli A, Cereda D, Coluccello A, Foti G, Fumagalli R, Iotti G, Latronico N, Lorini L, Merler S, Natalini G, Piatti A, Ranieri MV, Scandroglio AM, Storti E, Cecconi M, Pesenti A et al (2020) COVID-19 Lombardy ICU Network. Baseline Characteristics and Outcomes of 1591 Patients Infected With SARS-CoV-2 Admitted to ICUs of the Lombardy Region, Italy. JAMA 323(16):1574-1581. https://doi.org/10.1001/jama.2020.5394. https://pubmed.ncbi.nlm. nih.gov/32250385/

56. Verdecchia P, Cavallini C, Spanevello A, Angeli F et al (2020) Eur J Intern Med S0953-6205(20)30151-5. https://doi.org/10.1016/j. ejim.2020.04.037. https://pubmed.ncbi.nlm.nih.gov/32336612/

57. Lei C, Qian K, Li T, Zhang S, Fu W, Ding M, Hu S et al (2020) Neutralization of SARS-CoV-2 Spike Pseudotyped Virus by Recombinant ACE2-Ig. Nat Commun 11(1):2070. https://doi. org/10.1038/s41467-020-16048-4

58. Lamas GA (2015) Cardiology Patient Page. Chelation Therapy: A new look at an old treatment for heart disease, particularly in diabetics. Circulation 131(21):e505-6. https://doi.org/10.1161/ CIRCULATIONAHA.114.010774. https://pubmed.ncbi.nlm.nih. gov/26015468/

59. Escolar E, Lamas GA, Mark DB, Boineau R, Goertz C, Rosenberg Y, Nahin RL, Ouyang P, Rozema T, Magaziner A, Nahas R, Lewis EF, Lindblad L, Lee KL et al (2014) The effect of an EDTAbased chelation regimen on patients with diabetes mellitus and prior myocardial infarction in the trial to assess chelation therapy (TACT). Circ Cardiovasc Qual Outcomes (1):15-24. https://doi. org/10.1161/CIRCOUTCOMES.113.000663. https://pubmed.ncbi. nlm.nih.gov/24254885/

Publisher's Note Springer Nature remains neutral with regard to jurisdictional claims in published maps and institutional affiliations. 